\title{
Processing Potato Growth Performance as Affected by Foliar Application of Seaweed Extract and Boron
}

\author{
Abido, A. I. A. ${ }^{(1)}$, A. A. A. Alkharpotly ${ }^{(2)}$, S. A. El-Hakim ${ }^{(3)}$, and \\ A. N. Abd El-Aziz (1) \\ ${ }^{(1)}$ Plant Prod. Dept, Fac. Agric. (Saba Basha), Alex. Univ. \\ ${ }^{(2)}$ Associate Prof. Veget. Crops, Fac. Agric. and Natl. Resour., Aswan Univ. \\ ${ }^{(3)}$ Nubaria Farm Manager, Chipsy for Food Industries Co.
}

\begin{abstract}
Potato (Solanum tuberosum L.) is a leading staple food in the diet of the world population and providing of regular caloric requirements for human and deliver many essential elements, and vitamins including $\mathrm{K}, \mathrm{P}, \mathrm{Mn}, \mathrm{Mg}$, foliate, vit. $\mathrm{C}$, and vit. $\mathrm{B}_{6}$. Increasing its potential yield could be hypothesized via environmental friendly agricultural supplements as seaweed extracts (SWEs) instead of mineral fertilization, and certain micronutrients as boron (B).Therefore, two field experiments were carried out during both seasons of 2016 / 2017 and 2017 / 2018, in a private farm, at El-Nobaria region, El-Behiera Governorate, Egypt, under open field conditions in sandy soil to investigate the effects of two independent variable as SWE (control, 1000 and 2000 $\mathrm{mg} / \mathrm{l}$ ), and $\mathrm{B}$ (control, 25, 50 and $75 \mathrm{mg} / \mathrm{l}$ ) and their combinations on the growth performance (i.e. vegetative growth-related attributes and the yield) of 'Caruso' potato cultivar. Both conducted experiments were factorial experiments laid out in randomized complete blocks design (RCBD), with three replicates. Each replicate included 12 treatments. All determined treatments were distributed randomly within each block. Foliar application of SWE $\times$ B at $2000 \times 75 \mathrm{mg} / \mathrm{l}$; brought about the highest mean values of the studied vegetative growth attributes (plant height [cm] and number of main stems / plant) compare with the other treatments during both seasons. Likewise, pertaining the tuber yield, the same combination; led to the highest mean values for number of tubers / plant, tuber fresh weight / plant (g), total yield / feddan, as compared with control treatment during both seasons. Hence, the above-mentioned combination is the appropriate for both tested independent variables for the best growth performance of the tested dependent variable (i.e., vegetative and yield attributes of the given cultivar).Nevertheless, applying SWE at $2000 \mathrm{mg} / \mathrm{I} \times \mathrm{B}$ at $50 \mathrm{mg} / \mathrm{l}$; brought about the best potato for processing.
\end{abstract}

Key words: Foliar application, seaweed extract (SWE), boron (B), potato (Solanum tuberosum L.), vegetative growth attributes, yield attributes.

\section{INTRODUCTION}

Potato (Solanum tuberosum L.) is a member of the family Solanaceae. It is a staple food prevailing worldwide with obvious large-scale production, consumption and affordability with easy availability in the market. It is one of the most remunerative and cost-effective crops for the farmers due to its higher yield capacity within a short time - course (Sati et al., 2017).

Nowadays, there is a high demand for good environment friendly agriculture practices as seaweed extracts (SWEs) and certain micronutrients as boron for the high production of quality and healthy food as potatoes to nourish the increasing population (Jayasinghe et al., 2016).

Seaweed extracts are, mostly, rich in natural plant promoting substances such as auxins and cytokinins, vitamins, and some macro-and micronutrients, 
lipids, proteins, carbohydrates, amino acids, osmo-protectants, antimicrobial compounds and minerals. The benefits of seaweed application in agricultural field are numerous and diverse such as increase agricultural production rather than the use of chemical fertilizers (Cassan et al., 1992). Seaweed extracts (SWEs) have been used as a foliar application to increase growth, yield and quality, nutrient uptake, photosynthetic pigments and resistance to stress factors of many crops including potato (Arafa et al., 2011, 2012, 2013; Calvo et al., 2014).

It is known that the Egyptian soils have low organic matter content and high soil $\mathrm{pH}$ levels, and are, generally, of low in moisture contents, high in lime content and fine-textured, which decreases the boron uptake by plants (Dursun et al., 2010). Many investigators are in favor of foliar application of boron (B) in addition to essential major elements, which can play a distinct role in increasing the yield of potato.

Also, reclaimed land is usually not rich in fertility and structure, which negatively affects the growing crops. In addition, the nutrients in the soil of the Nile valley have been depleted due to the applied intensive agricultural systems. Therefore, a precise fertilization program has to be designed and applied to each type of soil in order to produce a better crop potentials.

Boron (B) plays an important role in physiological and biochemical events that occur in plants (Saleem et al., 2011), Also, Boron (B) plays a crucial roles in cell wall synthesis, sugar transport, cell division, cell development, auxin metabolism, good pollination and fruit set, seed development, synthesis of amino acids and proteins, nodule formation in legumes and regulation of carbohydrate metabolism (El-Dissoky and Abdel-Kadar, 2013).

Therefore, developing good management practices of both independent variables (i.e. seaweed extract and boron and their interaction) for potato growers was selected and undertaken in the present research to: 1) evaluate the response of potato cultivar 'Caruso' to the both tested independent variable levels, and 2) examine the interaction effect between SWE and boron levels on the growth performance of potato plant 'Caruso' cultivar (i.e., vegetative, yield and quality).

\section{MATERIALS AND METHODS}

Two field experiments were carried out during both seasons of 2016 / 2017 and 2017 / 2018, in a private farm, at El-Nobaria region, El-Behiera Governorate, Egypt, under open field conditions in sandy soil as given in Table (1).

The experimental field was ploughed and pulverized. Then, the soil was ridged into rows $0.80 \mathrm{~m}$ width and divided to plots. The potato seeds of 'Caruso' cultivar were derived from summer season and stored under cold conditions $\left(4{ }^{\circ} \mathrm{C}\right.$ and R.H. $95 \%$ ) were used in this study. 
Table (1). Some physical and chemical properties of the experimental site during both seasons of the experimentation (2016 / 2017 and 2017 / 2018)

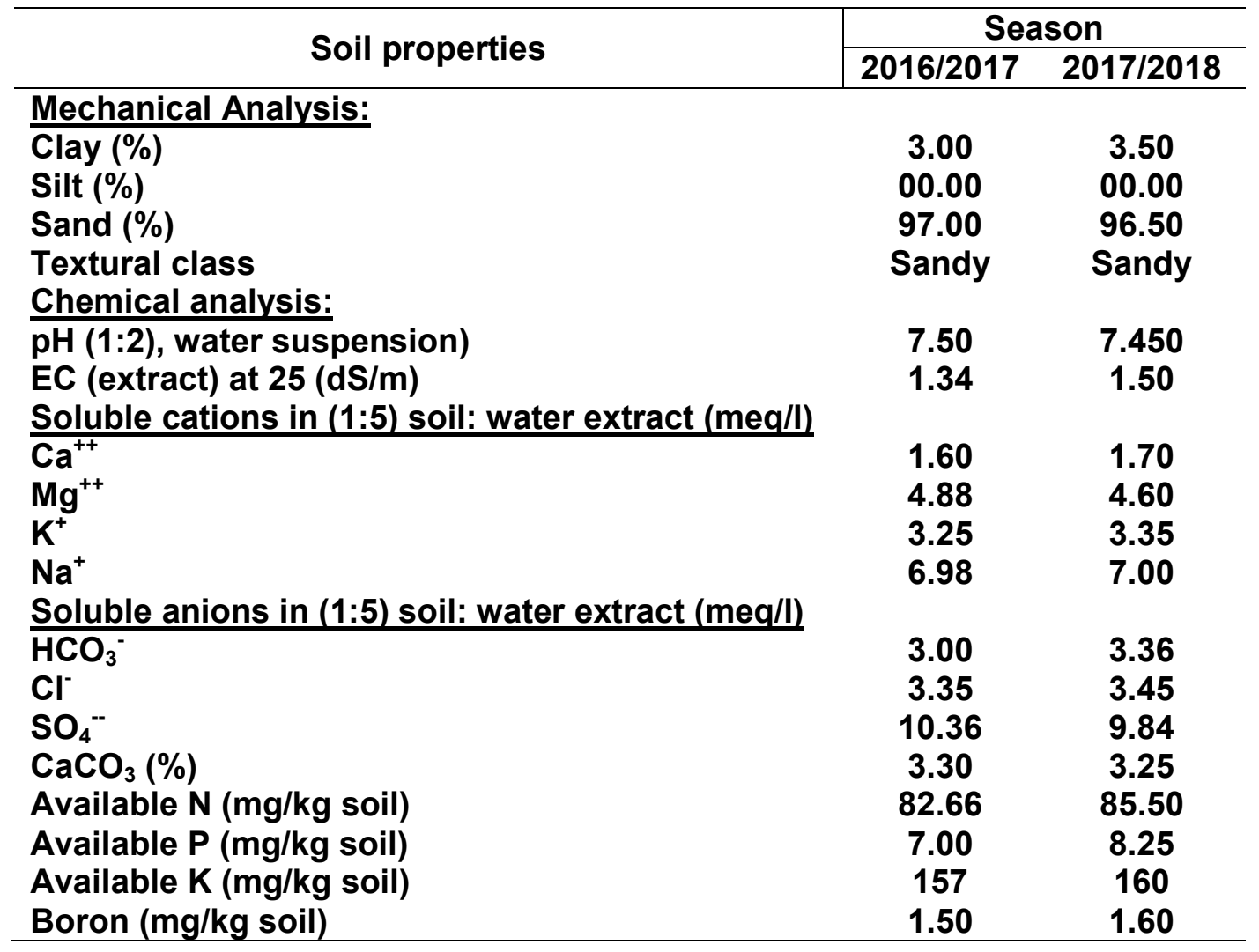

The experimental treatments and statistical design

The outcome treatments of the various tested combinations were consisted of both two factors (two independent variables) as foliar applicants, i.e.; three concentrations of seaweed extract (SWE) as control, 1000, and $2000 \mathrm{mg} / \mathrm{I}$ and four concentrations of boron (B) as control, 25, 50, and $75 \mathrm{mg} / \mathrm{I}$ either individually or in combinations. Control plants were sprayed with tap water. Seaweed extract coined as 'Oligo-x' was used in this study. It is a mixed from Ascophyllum, Laminaria, Sargassum, Fucus spp. It was obtained from Union for Agricultural Development Company having the following composition: oligosaccharides $3 \%$, algnic acid $5 \%$, phytin $0.003 \%$, menthol $0.001 \%$, natural growth regulators (Cytokinin $0.001 \%$, indoleacetic acid $0.0002 \%$ ), pepsin $0.02 \%$ and minerals (potassium oxide $12 \%$, phosphorus oxide $0.5 \%$, N $1 \%$, Zn $0.3 \%$, Fe $0.2 \%$ and $\mathrm{Mn}$ $0.1 \%)$.

Boron as boric acid $\left(\mathrm{H}_{3} \mathrm{BO}_{3}\right)[\mathrm{MW}=61.83]$ contained $17 \% \mathrm{~B}$ was purchased from Algomhoria Company for Chemicals, Alexandria, Egypt. 
Both conducted experiments were factorial experiments laid out in a randomized complete block design (RCBD), with three replicates. Each replicate included 12 treatments. All determined treatments were randomly distributed within each block. The experimental plot consisted of two ridges with $7.00 \mathrm{~m}$ long and $0.80 \mathrm{~m}$ width; making an area of $11.20 \mathrm{~m}^{2}$.

Potato plants were sprayed with the allocated or assigned treatments twice, the first one was executed after 55 days of planting, the second application was achieved after 15 days of the first one. The recommended agricultural practices were followed.

\section{Experimental data collections}

1-Vegetative growth - related characters included:

- Number of main stems per plant

- Plant height $(\mathrm{cm})$

\section{2-Yield and its component measurements included:}

- Number of tubers per plant

- Tuber fresh weight (g)

- Average of tuber yield per plant (g)

- Total tubers yield per feddan (ton)

\section{3- Tubers Quality included:}

- Potato yield accepted for processing: The suitable tubers for processing per plot were selected, weighted and converted into tons/fed, then calculated as percentage from total yield per feddan.

- The number of tubers / $10 \mathrm{~kg}$, it was determined by taking a random sample of $10 \mathrm{~kg}$ of tubers from the yield of each treatment and then counted. Number of potato tubers / $10 \mathrm{~kg}$ is a character of the processing Companies to receive potatoes. The accepted range of the number of tubers / $10 \mathrm{~kg}$ is $72-112$ tubers (Frito lay company, 1999), more than this numbers means small tubers and consequently small slides of chips which reduce the chip quality. If it was less than that range it means the presence of over-size large tubers, which may comprises hallow hart and cracks. Such defects may cause the rejection of the chips after processing.

- Specific gravity, was determined using the method described by Dinesh et al. (2005) and calculated from equation of Smith (1977) as follows:

Specific gravity $=$

Weight of tuber in air

$$
\begin{gathered}
\text { Weight of tuber in air - Weight of tuber under } \\
\text { water }
\end{gathered}
$$

- Tuber under size (<35 mm, \%), was determined using a micrometer (caliper) to measure all tubers under size ( $>35 \mathrm{~mm}$ ) per plot and counted, then calculated as a percentage of the total number of harvested tubers / plot. 
- Tubers dry matter (\%) was carried out via randomly tuber samples of $100 \mathrm{~g}$ of fresh weight which were dried in an electrical oven at $70{ }^{\circ} \mathrm{C}$ till the constant weight, then the obtained value of tuber dry matter was calculated as percentage.

- Chips defect evaluation, was calculated by showing the size limits $(1 / 2 \mathrm{~cm})$ for sugar browning and defects using chip-check chart method to determine the internal, external and undesirable color defects and dividing the defects to three categories; the first green from $0-8 \%$ defects are acceptable potato chips, the second yellow 8 - $15 \%$ defects are acceptable potato chips but with discarding the percentage over $8 \%$ and the third red $>15 \%$ defects are rejected and not suitable for processing according to (Frito Lay Company, 1999).

\section{Statistical Analysis:}

All obtained data of the present study were, statistically, analyzed according to the design used by the MSTAT-C computer software program (Bricker, 1991) and were tested by analysis of variance. The least significant difference test at 0.05 level of probability was used to compare the differences among the means of the various treatment combinations as illustrated by Gomez and Gomez (1984).

\section{RESULTS AND DISCUSSIONS}

\section{A. Vegetative growth-related characters}

Generally, Results presented in Table (2), reveal that the main effects of both SWE and $\mathrm{B}$ exhibited a direct proportional relationship with both tested traits, during both seasons, for the vegetative growth- related characters significantly $(p \leq 0.05)$.

The foliar application of potato plants with SWE especially at $2000 \mathrm{mg} / \mathrm{l}$; accounted for recording the highest average values compare with control treatment (foliar application with tap water). The increment percentages as an average of both seasons compare to control plants were 42.29 and $24.38 \%$ for number of main stems/plant and plant height characters, consecutively. These results are in agreement, more or less, with those of Demir et al. (2006) on tomato, pepper and eggplant plants, Abdulraheem (2009) on cucumber, Prasad et al. (2010) and Spinelli et al. (2010) on strawberry. Sridhar and Rengasamy (2012) on chilli pepper, Marhoon and Abbas (2015) on two sweet pepper cultivars, whereas the authors attributed this result due to the mode of action of cytokinins involved in SWE. Also, this finding may be taken place owing to break the apical dominance; hence accelerated the outgrowth of axillary branches and /or the ratio of cytokinin/ auxin, which regulates the growth and development all the other vegetative-related characters (George et al., 2008 a and b).

Likewise, they enhance plants' resistance to biotic and abiotic stresses due to their direct effect on metabolic pathways; resulting in formation antioxidant molecules in plant cells (Thirumaran et al., 2009 a, b). 
Table (2).Average values of some vegetative growth-related characters of potato plants CV. 'Caruso' as affected by foliar application with seaweed extract (SWE), Boron (B) and their combinations during the winter seasons of $2016 / 2017$ and $2017 / 2018$

\begin{tabular}{|c|c|c|c|c|c|}
\hline \multirow{2}{*}{\multicolumn{2}{|c|}{ Treatments }} & \multicolumn{2}{|c|}{ No. of main stems/plant } & \multicolumn{2}{|c|}{ Plant height (cm) } \\
\hline & & 2016/2017 & $2017 / 2018$ & 2016/2017 & 2017/2018 \\
\hline \multicolumn{6}{|c|}{ SWE (main effect) } \\
\hline \multirow{2}{*}{\multicolumn{2}{|c|}{$\begin{array}{l}\text { Control } \\
1000 \text { ma. }\left.\right|^{-1}\end{array}$}} & $3.69 \mathrm{c}$ & $3.83 \mathrm{c}$ & $55.05 \mathrm{c}$ & $55.88 \mathrm{c}$ \\
\hline & & $5.04 \mathrm{~b}$ & $5.08 \mathrm{~b}$ & $66.94 \mathrm{~b}$ & $67.94 \mathrm{~b}$ \\
\hline \multicolumn{2}{|c|}{$2000 \mathrm{mg} \cdot \mathrm{I}^{-1}$} & $5.33 \mathrm{a}$ & $5.37 \mathrm{a}$ & $68.88 \mathrm{a}$ & $69.10 \mathrm{a}$ \\
\hline \multicolumn{6}{|c|}{ B (main effect) } \\
\hline \multirow{2}{*}{\multicolumn{2}{|c|}{$\begin{array}{l}\text { Control } \\
25 \mathrm{mq}^{-1} \mathrm{I}^{-1}\end{array}$}} & $3.99 \mathrm{~d}$ & $4.15 \mathrm{~d}$ & $59.61 \mathrm{~d}$ & $60.88 d$ \\
\hline & & $4.42 \mathrm{c}$ & $4.40 \mathrm{c}$ & $62.16 \mathrm{c}$ & $62.59 \mathrm{c}$ \\
\hline \multicolumn{2}{|l|}{$50 \mathrm{mg}^{-1}$} & $4.98 \mathrm{~b}$ & $5.04 \mathrm{~b}$ & $64.57 \mathrm{~b}$ & $64.58 \mathrm{~b}$ \\
\hline \multicolumn{2}{|c|}{$75{\mathrm{mg} . \mathrm{I}^{-1}}^{-1}$} & $5.37 \mathrm{a}$ & $5.44 \mathrm{a}$ & $68.16 \mathrm{a}$ & $69.18 \mathrm{a}$ \\
\hline \\
\hline & & \multicolumn{4}{|c|}{$\operatorname{SWE}\left(\mathrm{mg} . \mathrm{I}^{-1}\right) \quad B\left(\mathrm{mg} . \mathrm{I}^{-1}\right)$} \\
\hline \multirow{4}{*}{ Control } & Control & $3.10 \mathrm{i}$ & $3.42 \mathrm{f}$ & $51.85 \mathrm{~h}$ & $53.81 \mathrm{~g}$ \\
\hline & 25 & $3.40 \mathrm{~h}$ & $3.53 \mathrm{f}$ & $54.43 \mathrm{~g}$ & $54.54 \mathrm{~g}$ \\
\hline & 50 & $4.10 \mathrm{~g}$ & $4.10 \mathrm{e}$ & $55.62 \mathrm{~g}$ & $55.23 \mathrm{~g}$ \\
\hline & 75 & $4.17 \mathrm{~g}$ & $4.27 \mathrm{e}$ & $58.32 \mathrm{f}$ & $59.92 \mathrm{f}$ \\
\hline \multirow{4}{*}{1000} & Control & $4.20 \mathrm{~g}$ & $4.30 \mathrm{e}$ & $62.40 \mathrm{e}$ & $63.14 \mathrm{e}$ \\
\hline & 25 & $4.90 \mathrm{e}$ & $4.80 \mathrm{~d}$ & $65.42 \mathrm{~cd}$ & $66.44 \mathrm{~d}$ \\
\hline & 50 & $5.23 d$ & $5.32 \mathrm{c}$ & $67.33 \mathrm{c}$ & $68.82 \mathrm{bc}$ \\
\hline & 75 & $5.83 \mathrm{~b}$ & $5.90 a \mathrm{~b}$ & $72.62 \mathrm{ab}$ & $73.35 \mathrm{a}$ \\
\hline \multirow{4}{*}{2000} & Control & $4.66 \mathrm{f}$ & $4.73 \mathrm{~d}$ & $64.59 \mathrm{~d}$ & $65.69 \mathrm{~d}$ \\
\hline & 25 & $4.97 \mathrm{e}$ & $4.86 \mathrm{~d}$ & $66.62 \mathrm{~cd}$ & $66.77 \mathrm{~cd}$ \\
\hline & 50 & $5.60 \mathrm{c}$ & $5.70 \mathrm{a}$ & $70.77 \mathrm{~b}$ & $69.67 \mathrm{~b}$ \\
\hline & 75 & $6.10 \mathrm{a}$ & $6.17 \mathrm{a}$ & $73.55 \mathrm{a}$ & $74.27 \mathrm{a}$ \\
\hline
\end{tabular}

-Values having the same alphabetical letter (s) in common, within each column, do not significantly differ, using L.S.D. test at 0.05 level of probability.

With regard to the main effect of $B$, it is clear also that there is a direct progressive relationship between $B$ concentrations and the dependent variable characters; whereas, foliar application of B at $75 \mathrm{mg} / \mathrm{I}$, exerted a significant ( $p \leq$ 0.05 ) effect on both tested traits, which brought about the highest average values of all tested traits compare to control plants, but intermediate values were recorded between both extreme levels. The increment percentages of both seasons compare to control plants were 32.80 and $13.98 \%$ for number of stems/plant and plant height characters, each in turn.

These results are in parallel with those of El-Banna and Abd El-Salam, 2005; El-Dissoky and Abdel-Kadar, 2013;Farouk, 2015; Muthanna et al., 2017; Tantawy et al., 2017; Alkharpotly et al., 2018; Ramesh et al., 2019. 
Number of stems/plant and plant height increments could be accounted for the physiological promotive effects mode of action of $B$, which enhance plant photosynthetic activity and concomitant vigour plant growth. Also, B has profound roles in cell wall synthesis, cell division, cell development, auxin metabolism and activation of different enzymes (Jafari-Jood et al., 2013). Likewise, B is an important agent for maintaining the structural integrity of cell wall and cell membranes (Zhang et al., 2014). Boron, also, helps in water and nutrient transportation from roots to shoots (Ziaeyan and Rajaie, 2012).

In terms of the first order interaction between both independent variables on vegetative-growth characters, it exerted significant $(p \leq 0.05)$ effect on various tested traits. Generally, it is obvious that under any concentration of SWE with B, more or less, the maximum average value of both studied traits compare to control plants was obvious. The interaction between SWE at either 1000 or $2000 \mathrm{mg} / \mathrm{I}$ with $B$ at $75 \mathrm{mg} / \mathrm{I}$, exhibited clear differences among tested treatments as number of main stems/plant and plant height as compared to control plants.

\section{B) Yield characters and its components:}

Concerning the results of Table (3), the average values of most tested yield characters were affected significantly $(p \leq 0.05)$ due to the main effects of both independent variables compare to their control treatments except for the number of tubers / plant character, which showed insignificant $(p>0.05)$ differences in its responses to main and interaction effects of both independent variables during both seasons.

With respect to the main effect of SWE, most tested traits were affected significantly $(p \leq 0.05)$ during both seasons. However, foliar application of SWE at 1000 or $2000 \mathrm{mg} / \mathrm{I}$; recorded the highest average values of tuber fresh weight, total yield / plant (g), total yield / feddan (ton) and the accepted yield for processing percentage compared to control plants during both seasons of the study. Whereas, control plants (sprayed with tap water) expressed the lowest significant average values of all tested yield characters during both seasons. 
Table (3). Averages values of some yield characters of potato plants cv. 'Caruso' as affected by foliar application with seaweed extract (SWE), Boron (B) and their combinations during the winter seasons of 2016/2017 and 2017/2018.

\begin{tabular}{|c|c|c|c|c|c|c|c|c|c|}
\hline \multirow{2}{*}{\multicolumn{2}{|c|}{ Treatments }} & \multirow{2}{*}{\multicolumn{2}{|c|}{ No. of tubers/plant }} & \multirow{2}{*}{\multicolumn{2}{|c|}{\begin{tabular}{|c}
$\begin{array}{c}\text { Tuber fresh weight } \\
(\mathrm{g})\end{array}$ \\
$2016 / 2017 \mid 2017 / 2018$
\end{tabular}}} & \multicolumn{2}{|c|}{\begin{tabular}{|c|}
$\begin{array}{c}\text { Total yield/plant } \\
(\mathrm{g})\end{array}$ \\
\end{tabular}} & \multicolumn{2}{|c|}{$\begin{array}{c}\text { Total yield/feddan } \\
\text { (ton) }\end{array}$} \\
\hline & & & $2017 / 2018$ & & & & & & \\
\hline \multicolumn{10}{|c|}{ SWE (main effect) } \\
\hline \multirow{2}{*}{\multicolumn{2}{|c|}{$\begin{array}{c}\text { Control } \\
1000 \mathrm{mg}^{-\mathrm{I}^{-1}}\end{array}$}} & $83 \mathrm{a}$ & $5.17 \mathrm{a}$ & $73.34 \mathrm{~b}$ & $75.14 \mathrm{~b}$ & $427.55 \mathrm{~b}$ & $388.45 b$ & $8.98 \mathrm{~b}$ & $8.16 \mathrm{~b}$ \\
\hline & & & & & & & & $10.22 \mathrm{a}$ & $11.06 \mathrm{a}$ \\
\hline \multicolumn{2}{|c|}{$2000 \mathrm{mg} \mathrm{I}^{-1}$} & $6.00 \mathrm{a}$ & $6.33 \mathrm{a}$ & $87.68 \mathrm{a}$ & $89.64 \mathrm{a}$ & 526.0 & $567.45 \mathrm{a}$ & $11.05 \mathrm{a}$ & $11.92 \mathrm{a}$ \\
\hline \multicolumn{10}{|c|}{$\bar{B}$ (main effect) } \\
\hline \multicolumn{2}{|c|}{ Control } & 33 a & $67 \mathrm{a}$ & $77.02 \mathrm{~d}$ & $78.87 \mathrm{~d}$ & $410.53 \mathrm{c}$ & $447.19 \mathrm{c}$ & $8.62 \mathrm{c}$ & 9.39 \\
\hline \multirow{2}{*}{\multicolumn{2}{|c|}{$25{\mathrm{mg} . \mathrm{I}^{-1}}^{-1}$}} & $4.89 a$ & $5.22 \mathrm{a}$ & $80.74 \mathrm{c}$ & $82.64 \mathrm{c}$ & $394.83 \mathrm{c}$ & $431.37 \mathrm{c}$ & $8.29 c$ & $9.06 \mathrm{c}$ \\
\hline & & $5.44 \mathrm{a}$ & 5.7 & & $7 \mathrm{~b}$ & $76 \mathrm{~b}$ & $7.48 \mathrm{~b}$ & $9.61 \mathrm{~b}$ & $10.45 \mathrm{~b}$ \\
\hline \multicolumn{2}{|c|}{$\begin{aligned} & 50 \mathrm{mg.} . I^{-1} \\
& 75 \mathrm{mg} . \mathrm{I}^{-1} \\
&\end{aligned}$} & $6.00 \mathrm{a}$ & $6.33 \mathrm{a}$ & $87.76 \mathrm{a}$ & & & & $11.06 \mathrm{a}$ & $11.93 \mathrm{a}$ \\
\hline \multicolumn{10}{|c|}{$\begin{array}{l}\text { Combinations effects } \\
\text { SWE }\left(\mathrm{mg} \mathrm{I}^{-1}\right) \mathrm{B}\left(\mathrm{mg} . \mathrm{I}^{-1}\right)\end{array}$} \\
\hline \multirow{4}{*}{ Control } & Control & $5.33 a$ & $5.67 \mathrm{a}$ & 69.60I & $71.35 I$ & $370.99 \mathrm{f}$ & $404.54 \mathrm{~g}$ & $7.79 \mathrm{f}$ & $8.50 \mathrm{~g}$ \\
\hline & 25 & $5.67 a$ & $5.50 \mathrm{a}$ & $72.15 \mathrm{k}$ & $73.93 \mathrm{k}$ & $409.09 \mathrm{e}$ & $406.64 \mathrm{~g}$ & $8.59 \mathrm{e}$ & $8.54 \mathrm{~g}$ \\
\hline & 50 & & & $74.27 \mathrm{j}$ & & $408.49 \mathrm{e}$ & $50 \mathrm{~g}$ & $8.58 \mathrm{e}$ & $8.52 \mathrm{~g}$ \\
\hline & 75 & $33 \mathrm{a}$ & $5.67 \mathrm{a}$ & $77.15 \mathrm{i}$ & $78.99 \mathrm{i}$ & $411.20 \mathrm{e}$ & $447.88 \mathrm{f}$ & $8.64 \mathrm{e}$ & $9.41 \mathrm{f}$ \\
\hline \multirow{4}{*}{1000} & Control & $5.67 \mathrm{a}$ & $5.00 \mathrm{a}$ & $79.64 \mathrm{~h}$ & $81.51 \mathrm{~h}$ & $451.53 \mathrm{~d}$ & $407.55 \mathrm{~g}$ & $9.48 \mathrm{~d}$ & $8.56 \mathrm{~g}$ \\
\hline & 25 & $5.70 \mathrm{a}$ & $5.67 \mathrm{a}$ & $83.52 \mathrm{f}$ & $85.45 f$ & $476.06 \mathrm{c}$ & $484.49 \mathrm{e}$ & $10.00 \mathrm{c}$ & $10.17 \mathrm{e}$ \\
\hline & 50 & $6.00 \mathrm{a}$ & $6.33 \mathrm{a}$ & $87.82 \mathrm{~d}$ & $89.78 \mathrm{~d}$ & $526.93 \mathrm{~b}$ & $568.34 \mathrm{c}$ & $11.07 \mathrm{~b}$ & $11.94 \mathrm{c}$ \\
\hline & 75 & $6.67 \mathrm{a}$ & $7.00 \mathrm{a}$ & $91.75 \mathrm{~b}$ & $93.76 \mathrm{~b}$ & $611.96 \mathrm{a}$ & $656.30 \mathrm{a}$ & $12.85 \mathrm{a}$ & $13.78 \mathrm{a}$ \\
\hline \multirow{4}{*}{2000} & Control & $5.00 \mathrm{a}$ & $5.33 \mathrm{a}$ & $81.37 \mathrm{~g}$ & $83.27 \mathrm{~g}$ & $406.86 \mathrm{e}$ & $443.83 \mathrm{f}$ & $8.54 \mathrm{e}$ & $9.32 \mathrm{f}$ \\
\hline & 25 & $5.67 a$ & $6.00 \mathrm{a}$ & $85.92 \mathrm{e}$ & $87.87 \mathrm{e}$ & $487.19 \mathrm{c}$ & $527.24 \mathrm{~d}$ & $10.23 \mathrm{c}$ & $11.07 \mathrm{~d}$ \\
\hline & 50 & $6.33 a$ & $6.67 \mathrm{a}$ & $89.52 \mathrm{c}$ & $91.51 \mathrm{c}$ & $566.67 \mathrm{~b}$ & $610.35 b$ & $11.90 \mathrm{~b}$ & $12.82 \mathrm{~b}$ \\
\hline & 75 & $7.00 \mathrm{a}$ & $7.33 \mathrm{a}$ & $93.41 \mathrm{a}$ & $95.43 \mathrm{a}$ & $653.84 \mathrm{a}$ & 699.48 a & $13.73 \mathrm{a}$ & $14.69 \mathrm{a}$ \\
\hline
\end{tabular}

Values having the same alphabetical letter (s) in common, within each column, do not significantly differ, using L.S.D. test at 0.05 level of probability.

The increment percentages of tested characters treated with $2000 \mathrm{mg} / \mathrm{l}$ (as an average of both seasons) compare to control plants were 19.42, 34.01, 34.01 and $5.2 \%$ for tuber fresh weight, total yield / plant (g), total yield / feddan (ton) and accepted yield for processing percentage, respectively. While, the increment percentages of tested characters treated with $1000 \mathrm{mg} / \mathrm{l}$ (as an average of both seasons) compare to control plants were $16.89,24.15,24.15$ and $4.40 \%$ for tuber fresh weight, total yield/plant (g), total yield / feddan (ton) and accepted yield for processing percentage, in series.

These results are in parallel with those of Awad et al. (2006); Sarhan (2011); Muhammad et al. (2012); Al-Bayati and Al-Quraishi (2019) on potato plants.

With regard to the main effect of $B$, it is clear that there is a direct proportional relationship between $\mathrm{B}$ concentrations and the dependent variable characters except for the number of tubers/plant character upon foliar application of $B$ at $75 \mathrm{mg} / \mathrm{l}$., compare with control plants (sprayed with tap water), which 
expressed the lowest significant values for tuber fresh weight $(\mathrm{g})$ and accepted yield for processing characters percentage.

The increment percentages of both seasons compare to control plants were $13.85,27.60,27.65$ and $4.47 \%$ for tuber fresh weight, total yield / plant $(\mathrm{g})$, total yield / feddan (ton) and accepted yield for processing percentage, each in turn.

These results are in parallel with those of El-Dissoky and Abdel-Kadar (2013); Farouk (2015); Tantawy et al. (2017); Alkharpotly et al. (2018); Manjunath et al. (2018); Sarkar et al. (2018 a,b); Singh et al. (2018) on potato plants.

In terms of the first order interaction between both independent variables on potato yield characters, it exerted significant $(p \leq 0.05)$ effect on various tested traits. Generally, it is obvious that under any concentration of SWE with B, more or less; caused the highest average values of the studied traits compare to control plants except for number of tubers / plant character. The interaction between SWE at either 1000 or 2000 mg / I with 50 or 75 mg / I B; exhibited clear differences on total yield / plant (g), total yield / feddan (ton) and accepted yield for processing percentage during both seasons compare to other tested treatments. About the average tuber fresh weight character (g), the interaction between SWE at $2000 \mathrm{mg}$ / I $\times 75 \mathrm{mg} /$ I B ; brought about the highest significant average values compare to other tested treatments during both seasons.

The increment percentages of $2000 \mathrm{mg} / \mathrm{l}$ SWE $\times 75 \mathrm{mg} / \mathrm{I} \mathrm{B}$ as an average of both seasons compare to control plants were 33.98, 74.50, 74.46 and $9.64 \%$ for tuber fresh weight, total yield / plant (g), total yield / feddan (ton) and accepted yield for processing percentage, each in turn.

The increment percentage points may be taken place due to applying a combination of $1000 \mathrm{mg} / \mathrm{I}$ SWE $\times 75 \mathrm{mg} / \mathrm{I}$ B as an average of both seasons compare to control plants were $63.53,73.47$ and $9.07 \%$ for total yield / plant (g), total yield / feddan (ton) and accepted yield for processing percentage, each in turn.

These results are in parallel with those of Abd El-Gawad and Osman (2014) on eggplant; whereas they reported that the highest values of yield and its components were achieved owing to foliar application of 1000 and 2000 ppm seaweed extract and $B$ at 50 ppm.

The increments of yield characters could be accounted for synchronization both applied independent variable levels, which may release phytohormones that stimulated plant growth and photosynthetic processes which enhanced vegetative growth characters as reported earlier, then caused increasing yield characters. 


\section{C) Tuber quality}

Results presented in Table (4) declare that both independent variable levels and their interactions affected significantly $(p \leq 0.05)$ the studied physical tuber quality traits of potato plants under the study.

Regarding the main effect of SWE levels, applying SWE at any real levels; decreased significantly $(p \leq 0.05)$ both number of tubers $/ 10 \mathrm{~kg}$ and percentage of tubers under size $(<35 \mathrm{~mm})$ compare to the control treatment plants (i.e. plants treated with SWE produced tubers with the largest size) during both seasons. On the contrary, applied SWE at either 1000 or $2000 \mathrm{mg} / \mathrm{l}$; produced tubers with higher specific gravity average values (1.10 and 1.10) [without significant difference] compare with untreated plants (1.08), i.e. untreated plants; produced tubers with lower specific gravity during both seasons. Similar trend of results were noticed for accepted yield for processing (\%).

Regarding the main effect of SWE independent variable, in general, showed a direct proportional relationship with tuber dry matter (\%), potato chips defect characters during both seasons of the study. In other words, as SWE foliar applied concentration increased; the average values of the studied traits increased progressively compare to control plants, especially at SWE level $2000 \mathrm{mg} / \mathrm{I}$. untreated plants showed the lowest significant values for all studied characters during both seasons.

The increment percentage points of the above-mentioned traits (an average of the highest tested concentration of both seasons versus control treatment) were as follows: 16.06 for tuber dry matter and 117.71 for potato chips defect percentages.

Tuber containing high dry matter is desirable for processing for a number of reasons: recovery (yield of processed product per unit of raw potatoes) is higher (Smith, 1977), the texture and flavor of the finished product is more desirable (Klienschimdt et al., 1984) and the cost of processing is low due to faster frying and less oil absorption (Gould, 1988). Many processing contracts after incentive to growers for delivering high specific gravity (high dry matter content) tubers. Tubers with high dry matter content require less energy input during frying or dehydration to remove water; they have greater product yield per unit fresh weight than tubers with lower solid content and absorb less oil during frying (Burton et al., 1992).

Potatoes with dry matter content of $20-24 \%$ are acceptable for making French fries and crisps while those with dry matter content up to $24 \%$ are ideal for preparing crisps (Kabira and Berga 2003). Kabira and Berga (2003) justified that potato tubers containing $20-24 \%$ dry matter produce fried products with high yields, less oil absorption and having better texture than those with lower solids. High dry matter has a direct effect on crisps and French fry yield as the weight of 
the processed product depends directly on the amount of dry matter present per quantitative weight of fresh potatoes (Burton et al., 1992).

These findings may be related to several direct and indirect mechanisms of SWE, including the stimulation of enzymatic activities related to carbon, nitrogen, metabolism, Krebs cycle, and glycosis. Such use may also induce activity similar to hormones and improve the nutrition status of treated plants with SWE foliar application.

In terms of the main effect of Boron (B) levels, the obtained results demonstrate that its foliar application at various levels; decreased significantly $(p \leq$ $0.05)$ number of tubers $/ 10 \mathrm{~kg}$ and tuber under size $(<35 \mathrm{~mm}$ ) especially at $75 \mathrm{mg}$ / I B compare to control plants, which recorded the highest average values for both characters, but the contrary was true for tuber specific gravity when potato plants treated with B at either 50 or $75 \mathrm{mg} / \mathrm{I}$ during both seasons compared to either control or plants treated with $25 \mathrm{mg} / \mathrm{I} \mathrm{B}$.

These findings could be accounted the role of SWE and B on the incidence of phenotypic changes in both directions of the tuber (longitudinally and dimensionally) and produced tubers with bigger size. Also, boron plays an active role in cell wall synthesis, cell division, cell development and activation of different enzymes which finally increased tuber size. The improved vegetative growth of plant and yield attributing characters due to SWE and boron application has a key function-as reported earlier- and direct relation in improvement tuber development and increase in tuber yield of medium and large size, i.e., the strong source-sink relationship.

Specific gravity of raw potatoes is widely accepted by the potato processing industry as a measure of total solids, starch concentration, and other qualities (Fitzpatrick et al., 1969). High and uniform specific gravity tubers have better quality and lower oil absorption when utilized for crisps (Kunkel et al., 1951 and Lana et al., 1970).

In the case of specific gravity, Khan et al. (2009) mentioned that potatoes with high specific gravity are preferred for preparation of chips and French fries, but potatoes with very high specific gravity (1.10) may not be suitable for French fries production, where they become hard or biscuit like products. The gained results showed that all tuber specific gravity values less than (1.10) were, more or less, recorded except that of either 1000 or $2000 \mathrm{mg} / \mathrm{I}$ SWE in combination with $75 \mathrm{mg}$ / I B treatment during both seasons of the study. As for accepted yield for processing (\%) trait, the obtained results elicited that this trait positively affected with increasing B concentration up to $75 \mathrm{mg} / \mathrm{I}$.

Likewise, these findings could be accounted for the SWE mode of action which could contribute to break down the polysaccharides of the cell wall, 
especially during maturing, and increasing sugars levels within tuber tissues, concomitant with the lowering of acidity inversely.

Plants treated with $B$ at the highest level $(75 \mathrm{mg} / \mathrm{I})$; showed the highest significant values for accepted yield for processing, tuber dry weight and potato chips defect percentages compare to control, which gave rise to the lowest significant values during both seasons. The increment percentage points compare to control plants (as an average of values of the highest level versus the control average values of both seasons) were $4.48 \%$ for accepted yield for processing, $11.50 \%$ for tuber dry matter and $89.17 \%$ for potato chips defect.

Regarding the first order interaction between both independent variables, tabulated results showed that dependent variable characters were affected significantly $(p \leq 0.05)$ due to the tested combinations.

Regarding the first order interaction between both independent variables, various tested combinations denoted to significant decreases between the control level of B variable under various levels of SWE; led to the highest average values of both number of tubers $/ 10 \mathrm{~kg}$ and percentage of tubers under size $(<35 \mathrm{~mm})$ characters (i.e. tubers with smallest size), during both seasons of the study.

Notably, at any tested level of SWE under the presence of B at $75 \mathrm{mg} / \mathrm{I}$, in general; led to the lowest index values (i.e. tubers with bigger size) compare to their control plants. However, tuber specific gravity index behaved oppositely to the above - mentioned characters; whereas, SWE at either 1000 or $2000 \mathrm{mg} / \mathrm{l}$ and the presence of B especially at either 50 or $75 \mathrm{mg} / \mathrm{I}$; give rise to the highest values of the given trait compare to its absence.

As for all of studied traits, direct proportional relationships were noticed at any levels of both independent variable levels. In other words, at any level of SWE, as $B$ level increased; the average values of tested traits increased, especially at 75 mg / I B versus control level of B at any level of SWE. Meanwhile, intermediate average values were significantly different from each other and from control treatments. These findings could be taken place due to the appropriate balance or ratio between cytokinins either added exogenously via seaweed extract or in vivo biosynthesized, in addition to exogenously applied B may stimulate various physiological processes, including those related to plant growth and development (Horgan, 1992; Strnad, 1997; Sakakibara, 2006; Frébort et al., 2011). Thus, each change in the level of applied SWE is concomitant with the endogenous cytokinins, affects the growth of entire plant attributes (Stirk and Van Staden, 2010; Zalabák et al., 2013).

In the review of literature of most published articles, most of plant responses that treated with biostimulant's as foliar application, especially seaweeds, were, most probably, derived from the presence of compounds of the category of plant 
hormones as cytokinins (Panda et al., 2012). Also, Korasick et al. (2013) concluded that auxins have a profound effect on many important stages of physiological growth in life cycle of plants. In other words, these findings could be taken place because of the higher constituents of SWE biostimulants as plant phytohormones (i.e. auxins, cytokinins, GAs, etc.) and other macro-and micronutrients which affected significantly the vital prerequites for plant growth and development (Masny and Zurawicz, 2004; Zodape et al., 2011; Mohammed, 2013).

This investigation provides the most appropriate findings to enhancement the growth performance of such processing potato cultivar "Caurso" grown at ElNobaria region, El-Behiera Governorate, Egypt, under open field conditions in clay loam soil via foliar application a combination of SWE at $2000 \mathrm{mg} / \mathrm{I}$ plus B at $75 \mathrm{mg}$ / I., for yield. Nevertheless, applying SWE at $2000 \mathrm{mg} / \mathrm{I} \times \mathrm{B}$ at $50 \mathrm{mg} \mathrm{/l;} \mathrm{brought}$ about the best combination for potato processing. 
Table (4). Averages values of some physical quality characters of potato tubers cv. 'Caruso' as affected by foliar application with seaweed extract (SWE), Boron (B) and their combinations during the winter seasons of 2016/2017 and 2017/2018

\begin{tabular}{|c|c|c|c|c|c|c|c|c|c|c|c|c|c|}
\hline \multirow{2}{*}{\multicolumn{2}{|c|}{ Treatments }} & \multicolumn{2}{|c|}{$\begin{array}{l}\text { Accepted yield for } \\
\text { processing (\%) }\end{array}$} & \multicolumn{2}{|c|}{$\begin{array}{c}\text { Number of } \\
\text { tubers/ } 10 \mathrm{~kg} .\end{array}$} & \multicolumn{2}{|c|}{\begin{tabular}{|c|}
$\begin{array}{c}\text { Tuber under size } \\
(>35 \mathrm{~mm})(\%)\end{array}$ \\
\end{tabular}} & \multicolumn{2}{|c|}{ Tuber specific gravity } & \multicolumn{2}{|c|}{ Tuber dry matter(\%) } & \multicolumn{2}{|c|}{$\begin{array}{c}\text { Potato chips defect } \\
(\%)\end{array}$} \\
\hline & & 2016/2017 & $2017 / 2018$ & $2016 / 2017$ & $2017 / 2018$ & 2016/2017 & $2017 / 2018$ & $2016 / 2017$ & $2017 / 2018$ & $2016 / 2017$ & $2017 / 2018$ & 2016/2017 & $2017 / 2018$ \\
\hline \multicolumn{14}{|c|}{ 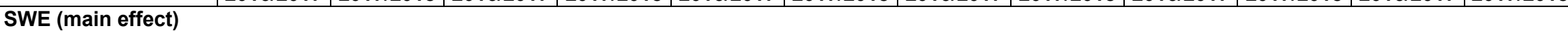 } \\
\hline $\begin{array}{l}\text { Control } \\
1000 \mathrm{mg} . \mathrm{I}-1 \text { (1) } \\
2000 \mathrm{mg} . \mathrm{l}-1 \text { ( }\end{array}$ & $\begin{array}{l}\text { WE) } \\
\text { WE) }\end{array}$ & $\begin{array}{l}88.62 b \\
93.01 a \\
93.47 a \\
\end{array}$ & $\begin{array}{l}90.96 \mathrm{~b} \\
94.47 \mathrm{a} \\
95.44 \mathrm{a} \\
\end{array}$ & $\begin{array}{l}136.36 \mathrm{a} \\
116.55 \mathrm{~b} \\
114.05 \mathrm{~b}\end{array}$ & $\begin{array}{l}133.09 \mathrm{a} \\
113.95 \mathrm{~b} \\
111.55 \mathrm{~b}\end{array}$ & $\begin{array}{l}5.73 a \\
2.31 b \\
2.02 c \\
\end{array}$ & $\begin{array}{l}6.01 a \\
2.63 b \\
2.37 c \\
\end{array}$ & $\begin{array}{l}1.08 b \\
1.10 a \\
1.10 a \\
\end{array}$ & $\begin{array}{l}1.08 b \\
1.10 a \\
1.10 a \\
\end{array}$ & $\begin{array}{l}20.40 \mathrm{c} \\
23.50 \mathrm{~b} \\
23.70 \mathrm{a} \\
\end{array}$ & $\begin{array}{l}20.70 c \\
23.70 b \\
24.00 a\end{array}$ & $\begin{array}{l}4.70 c \\
8.58 b \\
10.09 a\end{array}$ & $\begin{array}{l}4.73 c \\
8.94 b \\
10.44 a\end{array}$ \\
\hline \multicolumn{14}{|c|}{$B$ (main effect) } \\
\hline $\begin{array}{l}\text { Control } \\
25 \mathrm{mg} . \mathrm{l}-1(\mathrm{~B}) \\
50 \mathrm{mg} \cdot \mathrm{l}-1(\mathrm{~B}) \\
75 \mathrm{mg} \cdot \mathrm{l}-1(\mathrm{~B})\end{array}$ & & $\begin{array}{l}89.51 d \\
91.13 c \\
92.43 b \\
93.74 a\end{array}$ & $\begin{array}{l}91.58 d \\
93.10 c \\
94.36 b \\
95.45 a\end{array}$ & $\begin{array}{l}129.83 \mathrm{a} \\
123.85 \mathrm{~b} \\
118.84 \mathrm{c} \\
113.95 \mathrm{~d}\end{array}$ & $\begin{array}{l}126.79 \mathrm{a} \\
121.01 \mathrm{~b} \\
116.18 \mathrm{c} \\
111.46 \mathrm{~d}\end{array}$ & $\begin{array}{c}4.66 \mathrm{a} \\
3.58 \mathrm{~b} \\
2.91 \mathrm{bc} \\
2.26 \mathrm{c}\end{array}$ & $\begin{array}{c}5.03 \mathrm{a} \\
3.91 \mathrm{~b} \\
3.24 \mathrm{bc} \\
2.50 \mathrm{c}\end{array}$ & $\begin{array}{l}1.08 \mathrm{c} \\
1.09 \mathrm{~b} \\
1.09 \mathrm{a} \\
1.10 \mathrm{a}\end{array}$ & $\begin{array}{l}1.09 \mathrm{c} \\
1.09 \mathrm{~b} \\
1.10 \mathrm{a} \\
1.10 \mathrm{a}\end{array}$ & $\begin{array}{l}21.10 d \\
22.10 c \\
23.20 b \\
23.60 a\end{array}$ & $\begin{array}{l}21.50 d \\
22.40 c \\
23.40 b \\
23.90 a\end{array}$ & \begin{tabular}{|c|}
$5.64 c$ \\
$6.79 c$ \\
$8.27 b$ \\
$10.47 a$ \\
\end{tabular} & $\begin{array}{c}5.72 c \\
7.07 b c \\
8.35 b \\
11.02 a\end{array}$ \\
\hline \multicolumn{14}{|c|}{$\begin{array}{l}\text { Combinations effects } \\
\text { SWE (mg.l-1) B ( mg.l-1) }\end{array}$} \\
\hline Control & $\begin{array}{c}\text { Control } \\
25 \\
50 \\
75\end{array}$ & \begin{tabular}{|c|}
$86.40 f$ \\
$88.48 \mathrm{e}$ \\
$89.37 \mathrm{de}$ \\
$90.22 \mathrm{de}$ \\
\end{tabular} & $\begin{array}{c}89.65 \mathrm{i} \\
90.52 \mathrm{hi} \\
91.36 \mathrm{hi} \\
92.31 \mathrm{gh}\end{array}$ & $\begin{array}{l}143.67 a \\
138.60 b \\
134.64 c \\
129.62 d\end{array}$ & $\begin{array}{l}140.16 a \\
135.26 b \\
131.44 c \\
126.60 d\end{array}$ & $\begin{array}{c}7.67 \mathrm{a} \\
6.00 \mathrm{~b} \\
4.90 \mathrm{bc} \\
4.33 \mathrm{~cd}\end{array}$ & $\begin{array}{c}7.81 \mathrm{a} \\
6.34 \mathrm{ab} \\
5.24 \mathrm{bc} \\
4.66 \mathrm{~cd}\end{array}$ & $\begin{array}{c}1.07 \mathrm{~g} \\
1.08 \mathrm{f} \\
1.09 \mathrm{e} \\
1.09 \mathrm{de}\end{array}$ & $\begin{array}{c}1.08 \mathrm{~g} \\
1.08 \mathrm{f} \\
1.09 \mathrm{e} \\
1.09 \mathrm{de}\end{array}$ & $\begin{array}{l}17.50 \mathrm{k} \\
19.90 \mathrm{j} \\
21.70 \mathrm{i} \\
22.10 \mathrm{~h}\end{array}$ & $\begin{array}{l}20.10 \mathrm{~h} \\
20.10 \mathrm{~h} \\
22.10 \mathrm{~g} \\
22.40 \mathrm{f}\end{array}$ & $\begin{array}{l}2.67 \mathrm{~g} \\
4.67 \mathrm{fg} \\
5.57 \mathrm{ef} \\
5.90 \mathrm{ef}\end{array}$ & $\begin{array}{c}2.81 \mathrm{~h} \\
4.58 \mathrm{gh} \\
5.63 \mathrm{fg} \\
5.91 \mathrm{e}-\mathrm{g}\end{array}$ \\
\hline 1000 & $\begin{array}{c}\text { Control } \\
25 \\
50 \\
75\end{array}$ & $\begin{array}{c}90.76 \mathrm{~cd} \\
92.30 \mathrm{~b} \mathrm{c} \\
93.60 \mathrm{ab} \\
95.38 \mathrm{a}\end{array}$ & $\begin{array}{c}91.75 \mathrm{gh} \\
94.17 \mathrm{~d}-\mathrm{f} \\
95.34 \mathrm{~b}-\mathrm{d} \\
96.63 \mathrm{ab}\end{array}$ & $\begin{array}{l}125.57 \mathrm{e} \\
119.73 \mathrm{~g} \\
113.87 \mathrm{i} \\
108.99 \mathrm{j}\end{array}$ & $\begin{array}{l}122.69 \mathrm{e} \\
117.03 \mathrm{~g} \\
111.38 \mathrm{i} \\
106.66 \mathrm{j}\end{array}$ & $\begin{array}{c}3.23 \mathrm{de} \\
2.63 \mathrm{ef} \\
2.07 \mathrm{e}-\mathrm{g} \\
1.30 \mathrm{~g}\end{array}$ & $\begin{array}{l}3.57 \mathrm{~d}-\mathrm{f} \\
2.96 \mathrm{e}-\mathrm{g} \\
2.39 \mathrm{e}-\mathrm{h} \\
1.60 \mathrm{gh}\end{array}$ & $\begin{array}{l}1.09 \mathrm{c}-\mathrm{e} \\
1.09 \mathrm{~b}-\mathrm{d} \\
1.10 \mathrm{a}-\mathrm{c} \\
1.10 \mathrm{ab}\end{array}$ & $\begin{array}{c}1.09 \mathrm{c}-\mathrm{e} \\
1.10 \mathrm{~b}-\mathrm{d} \\
1.10 \mathrm{a}-\mathrm{c} \\
1.10 \mathrm{a}\end{array}$ & $\begin{array}{l}22.70 \mathrm{~g} \\
23.20 \mathrm{e} \\
23.70 \mathrm{c} \\
24.10 \mathrm{~b}\end{array}$ & $\begin{array}{l}23.20 \mathrm{e} \\
23.60 \mathrm{~d} \\
24.00 \mathrm{c} \\
24.30 \mathrm{a}\end{array}$ & $\begin{array}{l}6.87 \mathrm{~d}-f \\
7.70 \mathrm{de} \\
8.57 \mathrm{~cd} \\
11.20 \mathrm{~b}\end{array}$ & $\begin{array}{l}6.97 d-g \\
8.23 c-e \\
8.72 c d \\
11.85 b\end{array}$ \\
\hline 2000 & $\begin{array}{c}\text { Control } \\
25 \\
50 \\
75 \\
\end{array}$ & $\begin{array}{c}91.37 \mathrm{~cd} \\
92.59 \mathrm{bc} \\
94.32 \mathrm{ab} \\
95.61 \mathrm{a}\end{array}$ & $\begin{array}{c}93.33 \mathrm{e}-\mathrm{g} \\
94.62 \mathrm{c}-\mathrm{e} \\
96.40 \mathrm{a}-\mathrm{c} \\
97.42 \mathrm{a}\end{array}$ & $\begin{array}{c}122.89 f \\
116.38 \mathrm{~h} \\
111.71 \mathrm{i} \\
107.06 \mathrm{j}\end{array}$ & $\begin{array}{c}120.09 \mathrm{f} \\
113.80 \mathrm{~h} \\
109.28 \mathrm{i} \\
104.79 \mathrm{j}\end{array}$ & $\begin{array}{c}3.07 \mathrm{de} \\
2.10 \mathrm{e}-\mathrm{g} \\
1.77 \mathrm{fg} \\
1.13 \mathrm{~g}\end{array}$ & $\begin{array}{c}3.72 \mathrm{de} \\
2.42 \mathrm{e}-\mathrm{h} \\
2.09 \mathrm{f}-\mathrm{h} \\
1.24 \mathrm{~h}\end{array}$ & $\begin{array}{c}1.09 \mathrm{c}-\mathrm{e} \\
1.10 \mathrm{a}-\mathrm{c} \\
1.10 \mathrm{a}-\mathrm{c} \\
1.10 \mathrm{a}\end{array}$ & $\begin{array}{c}1.09 \mathrm{~b}-\mathrm{d} \\
1.10 \mathrm{a}-\mathrm{c} \\
1.10 \mathrm{ab} \\
1.10 \mathrm{a} \\
\end{array}$ & $\begin{array}{l}22.90 \mathrm{f} \\
23.50 \mathrm{~d} \\
23.70 \mathrm{c} \\
24.30 \mathrm{a}\end{array}$ & $\begin{array}{l}23.20 \mathrm{e} \\
23.60 \mathrm{~d} \\
24.20 \mathrm{~b} \\
24.30 \mathrm{a}\end{array}$ & $\begin{array}{c}7.40 \mathrm{de} \\
8.00 \mathrm{de} \\
10.67 \mathrm{bc} \\
14.30 \mathrm{a}\end{array}$ & $\begin{array}{c}7.38 d-f \\
8.39 c-e \\
10.70 b c \\
15.29 a\end{array}$ \\
\hline
\end{tabular}

- Values having the same alphabetical letter (s) in common, within each column, do not significantly differ, using Duncan's Multiple Range

Test at 0.05 level of probability. 


\section{REFERNCES}

Abd El-Gawad, H. G. and H. S. Osman (2014). Effect of exogenous application of boric acid and seaweed extract on growth, biochemical content and yield of eggplant. J. Hort. Sci. \& Ornam. PI., 6 (3): 133-143.

Abdulraheem, S. M. (2009). Effect of nitrogen fertilizer and seaweed extracts on vegetative growth and yield of cucumber. Diyala Agric. Sci. J., 1:134-145.

Al-Bayati, H. J. M. and G. M. A. Al-Quraishi (2019). Response of three potato varieties to seaweed extracts. Kufa J. Agric. Sci., 11 (1): 36-40.

Alkharpotly, A., A. Roshdy and E. Mady (2018). Potato growth and yield attributes as affected by Boron and Selenium foliar application. J. PI. Prod. Mansoura Univ., 9 (11).

Arafa A. A., S. Farouk and H. S. Mohamed (2011). Effect of potassium fertilizer, biostimulants and effective microorganisms as well as their interactions on potato growth, photosynthetic pigments and stem anatomy. J. Pl. Prod., Mansoura Univ., 2(8):1017-1035.

Arafa, A. A., S. Farouk and H. S. Mohamed (2012). Response of tuber yield quantity and quality of potato plants and its economic consideration to certain bioregulators, effective microorganisms under potassium fertilization. J. PI. Prod. Mansoura Univ., 3(1):131-150.

Arafa, A. A., S. Farouk and H. S. Mohamed (2013). Effect of potassium fertilizers, biostimulants and effective microorganisms of growth, carbohydrates concentration and ion percentage in the shoots of potato plants. J. PI. Prod. Mansoura Univ., 4 (1):15 - 32.

Awad, E. M. M., N. S. Youssef and Z. S. El-Shall (2006). Effect of foliar spraying with seaweed extracts and inorganic fertilizers levels on growth, yield and quality of potato crop. J. Agric. Sci., Mansoura Univ., 31 (10): 6549-6559.

Bricker, B. (1991). MSTATC: A Micro Computer Program from the Design Management and Analysis of Agronomic Research Experiments. Michigan State Univ., USA.

Burton, W. G., A. Van Es and K. J. Hartmans (1992). The physics and physiology of storage. In: Harris PM (ed) The potato crop, 2nd ed. Chapman and Hall, London, pp: 608-727.

Calvo, P., L. Nelson and J. W. Kloepper (2014). Agricultural uses of plant biostimulants. PI. \& Soil, 383:3-41.

Cassan L., I. Jean, J. Lamaze and J. F. Morotgaudry (1992). The effect of the Ascophylum nodosum extract Geomer $\mathrm{GA}_{14}$ on the growth of spinach. Bot. Mar., 35: 437-439.

Demir, N., B. Dural and K. Yildirim (2006). Effect of seaweed suspensions on seed germination of tomato, pepper and aubergine. J. Biol. Sci., 6(6): 11301133.

Dinesh, K., R. Ezekiel, B. Singh and I. Ahmed (2005). Conversion table for specific gravity dry matter and starch content from under water weight of potatoes grown in North India plains. Potato J., 32 (1-2): 79-84. 
Dursun, A., M. Turan, M. Ekinci, A. Gunes, N. Ataoglu, A. Esringü and E. Yıldırım (2010). Effects of boron fertilizer on tomato, pepper, and cucumber yields and chemical composition. Comm. Soil Sci. \& PI. Anal., 41:15761593.

El-Banna, E. N. and H. Z. Abd El-Salam (2005). Response of potato plants for different sources of potassium with different foliar rates of boron and molybdenum. J. Agric. Sci. Mansoura Univ., 30 (10): 6221-6233.

El-Dissoky, R. A. and A. E. S. Abdel-Kadar (2013). Effect of boron as a foliar application on some potato's cultivars under Egyptian alluvial soil conditions. Res. J. Agric. \& Biol. Sci., 9(5): 232-240.

Farouk, S. (2015). Improving growth and productivity of potato (Solanum tuberosum L.) by some biostimulants and lithovit with or without boron. J. PI. Prod., Mansoura Univ., 6 (12): 2187-2206.

Fitzpatrick, T. J., W. L. Porter and G. V. Hoghland (1969). Continued studies of the relationship of specific gravity to total solids of potatoes. Amer. Potato J., 46(4):120-127.

Frébort, I., M. Kowalska, T. Hluska, J. Frébortová and P. Galuszka (2011). Evolution of cytokinin biosynthesis and degradation. J. Exp. Bot., 62(8): 2431-2452.

Frito Lay Company (1999). Potato sending Manual. Operations quality system department. Leicester, United Kingdom.

George, E. F., M. A. Hall and G. J. De Klerk (2008 a). Plant growth regulators II: cytokinins, their analogues and antagonists. In Plant propagation by tissue culture (pp. 205-226). Springer, Dordrecht.

George, E. F., M. A. Hall, and G. J. De Klerk.(2008 b)."Plant tissue culture procedure-background. "Plant propagation by tissue culture. Springer, Dordrecht., 1-28.

Gomez, K. A. and A. A. Gomez (1984). Statistical Procedures for Agricultural Research. John Wiley and Sons. Inc., New York.

Gould, W. A. (1988). Quality of potatoes for chip manufacture. In: Symposium on potato quality: Industry needs, for growth. The potato Association of America. Fort Collins, CO. p. 10-20.

Horgan, R. (1992). Present and future prospects for cytokinin research. physiology and biochemistry of cytokinins in plants, pp 3-14. The Hague, The Netherlands: SPB Academic Publ.

Jafari-Jood, S., A. H. Shiranirad, J. Daneshian and A. Rokhzadi (2013). Effects of nitrogen application and spraying of boron and manganese on growth traits of two potato cultivars. Intl. J. BioSci., 3(9): 298-303.

Jayasinghe, P. S., V. Pahalawattaarachchi and K. Ranaweera (2016). Effect of seaweed liquid fertilizer on plant growth of Capsicum annuum. Discovery, 52(244): 723-734.

Kabira, J. and L. Berga (2003). Potato processing quality evaluation procedures for research and food industry applications in East and Central Africa. Kenya Agricultural Research Institute, Nairobi, Kenya. 
Khan, W., U. Rayirath, S. Subramanian, M. Jithesh, P. Rayorath, D. M. Hodges, A. Critchley, J. Craigie, J. Norrie and B. Prithiviraj (2009). Seaweed extracts as biostimulants of plant growth and development. J. Plant Growth Reg., 28(4): 386-399.

Klienschimdt, G. D., G. E. Klienkopf, D. T. Westermann and J. C. Zalewski (1984). Specific gravity of potatoes CIS 609.University of Idaho College of Agriculture, Cooperative Extension System. Moscow, ID. 4pp.

Korasick, D. A., T. A. Enders and L. C. Strader (2013). Auxin biosynthesis and storage forms. J. Exp. Bot., 64 (9): 2541-2555.

Kunkel, R., J. Gregory and A. M. Binkley (1951). Mechanical separation of potatoes into specific gravity groups shows promise for the potato chip industry. Amer. Potato J., 28:690-696. Potato Research (2010) 53:95-109.

Lana, E. P., R. H. Johnson and D. C. Nelson (1970). Variations in specific gravity of potato tubers. Amer. Potato J., 47 (1):9-12.

Manjunath, R. P., V. M. Anjanappa, G. K. Ramegowda, S. Anilkumar and P.S. Prasad (2018). Influence of foliar spray of micronutrient formulation on

quality and shelf life of potato (Solanum tuberosum L.). Intl. J. Pure. Appl. BioSci., 6(1): 660-665.

Marhoon, I. A. and M. K. Abbas (2015). Effect of foliar application of seaweed extract and amino acids on some vegetative and anatomical characters of two sweet pepper (Capsicum AnnuumL.) cultivars. Intl. J. Res. Stud. Agric. Sci. (IJRSAS) 1(1): 35-44.

Masny, A. B. and E. Zurawicz (2004). Effect of applications of Kelpak SL. and Goremar BM 86, preparation on yield and fruit quality in two strawberry cultivars. Res. Instit. Pomo.\& Floricul. Pomo.,18:96-100.

Mohammed, G. H. (2013). Effect of seamino and ascorbic acid on growth, yield and fruits quality of pepper (Capsicum annum L). Intl. J. Pure Appl. Sci. Technol., 17(2): 9-16.

Muhammad, W. H., C. M. Ayyub, M. A. Pervez, H. U. Asad, A. Manan, S. A. Raza and I. Ashraf (2012). Impact of foliar application of seaweed extract on growth, yield and quality of potato (Solanum tuberosum L.). Soil Environ. 31(2):157-162.

Muthanna, M. A., A. K. Singh, A. Tiwari, V. K. Jain and M. Padhi (2017). Effect of boron and sulphur application on plant growth and yield attributes of potato (Solanum tuberosum L.). Intl. J. Curr. Microbiol. Appl. Sci.,6(10): 399404.

Panda, D., K. Pramanik and B. R. Nayak (2012). Use of seaweed extracts as plant growth regulators for sustainable agriculture. Int. J. Biores. Stress Manag., 3(3), 404-411.

Prasad, K., A. K. Das, M. D. Oza, H. Brahmbhatt, A. K. Siddhanta, R. Meena, K. E. Eswarn, M. R. Rrajyaguru and P. K. Ghosh (2010). Detection and quantification of some plant growth regulators in a seaweed-based foliar spray employing a mass spectrometric technique sans chromatographic separation. J. Agric. Food Chem., 58 (8): 4594-4601. 
Ramesh, E., J. C. Jana, R. Chatterjee and G. C. Banik (2019). Effect of foliar application of secondary and micronutrients on growth and yield of potato. J. Pharm. \& Phytochem., 8(2): 656-660.

Sakakibara, H. (2006). Cytokinins: activity, biosynthesis, and translocation. Ann. Rev. PI. Biol., 57: 431-449.

Saleem M., Y. M. Khanif, I. Fauziah, A.W. Samsuri and B. Hafeez (2011). Importance of boron for agriculture productivity. Inte. Res. J. Agric. Sci. \& Soil Sci., 1(8): 293-300.

Sarhan, T. Z. (2011). Effect of humic acid and seaweed extracts on growth and yield of potato plant (Solanum tubersum L) Desiree cV. Mesopotamia J. Agric., 39(2): 19-25.

Sarkar, S., H. Banerjee, I. Chakraborty, S. Sau, K. Ray, D. Ghosh and P. Deb (2018 a). Assessment of growth, yield, tuber quality and profitability of potato upon boron fertilization. J. Environ., Biol., 39 365-372.

Sarkar, S., H. Banerjee, K. Rayc and D. Ghosha (2018 b). Boron fertilization effects in processing grade potato on an Inceptisol of West Bengal, India. J. PI. Nutr., 1-13.

Sati, K., M. Raghav, U.C. Sati and A. M. Lavlesh (2017). Effect of zinc sulphate application on quality of potato. Res. Crops, 18 (1): 98-102.

Singh, S. K., M. Sharma, K. R. Reddy and T. Venkatesh (2018). Integrated application of boron and sulphur to improve quality and economic yield in potato. J. Environ. Biol., 39: 204-210.

Smith, O. (1977). Potatoes: production, storing and processing. The AVI Publishing company, Westport, Connecticut, USA. Second edition. pp. 222302.

Spinelli, F., G. Fiori, M. Noferini, M. Sprocatti and G. Costa (2010). A novel type of seaweed extract as a natural alternative to the use of iron chelates in strawberry production. Sci. Hort., 125(3): 263-269.

Sridhar, S. and R. Rengasamy (2012). The effect of Sargassum wightii extract on the growth, biochemical composition and yield of Capsicum annum under field trial. Intl. J. Curr. Sci., 4:35-43.

Stirk, W. A. and J. Van Staden (2010). Flow of cytokinins through the environment. PI. Grow. Regul., 62(2):101-116.

Strnad, M. (1997). The aromatic cytokinins. Physiol. PI., 101(4):674-688.

Tantawy, A. S., Y. A. Salama, S. A. Saleh and A. A. Ghoname (2017). Enhancing yield and quality of two potato cultivars by using boron foliar application. Mid. East J. Appl. Sci., 7(3): 510-518.

Thirumaran, G., M. Arumugam, R. Arumugam and P. Anantharaman (2009 a). Effect of seaweed liquid fertilizer on growth and pigment concentration of Cyamopsistetr ogonolaba(L) Taub. Amer.-Eura. J. Agron., 2 (2): 50-56.

Thirumaran, G., M. Arumugam, R. Arumugam and P. Anantharaman (2009 b). Effect of seaweed liquid fertilizer on growth and pigment concentration of Abelmoschus esculentus (1) medikus. Amer.-Eura. J. Agron., 2 (2): 57-66.

Zalabák, D., H. Pospíšilová, M. Šmehilová, K. Mrízová, I. Frébort and P. Galuszka (2013). Genetic engineering of cytokinin metabolism: prospective 
way to improve agricultural traits of crop plants. Biotechnol. Adv., 31(1):97117.

Zhang, D., H. Zhao, L. Shi and F. Xu (2014). Physiological and genetic responses to boron deficiency in Brassica napus: A review. Soil Sci. \& PI. Nutr., 60(3): 304-313.

Ziaeyan, A. H. and M. Rajaie (2012). Combined effect of zinc and boron on yield and nutrients accumulation in corn. Intl. J. PI. Prod., 3(3):35-44.

Zodape, S. T., A. Gupta and S.C. Bhandari (2011). Foliar application of seaweed sap as biostimulant for enhancement of yield and quality of tomato (Lycopersicon esculentum Mill.). J. Sci. \& Industrial Res., 70: 215-219.

\section{الملخص العربي}
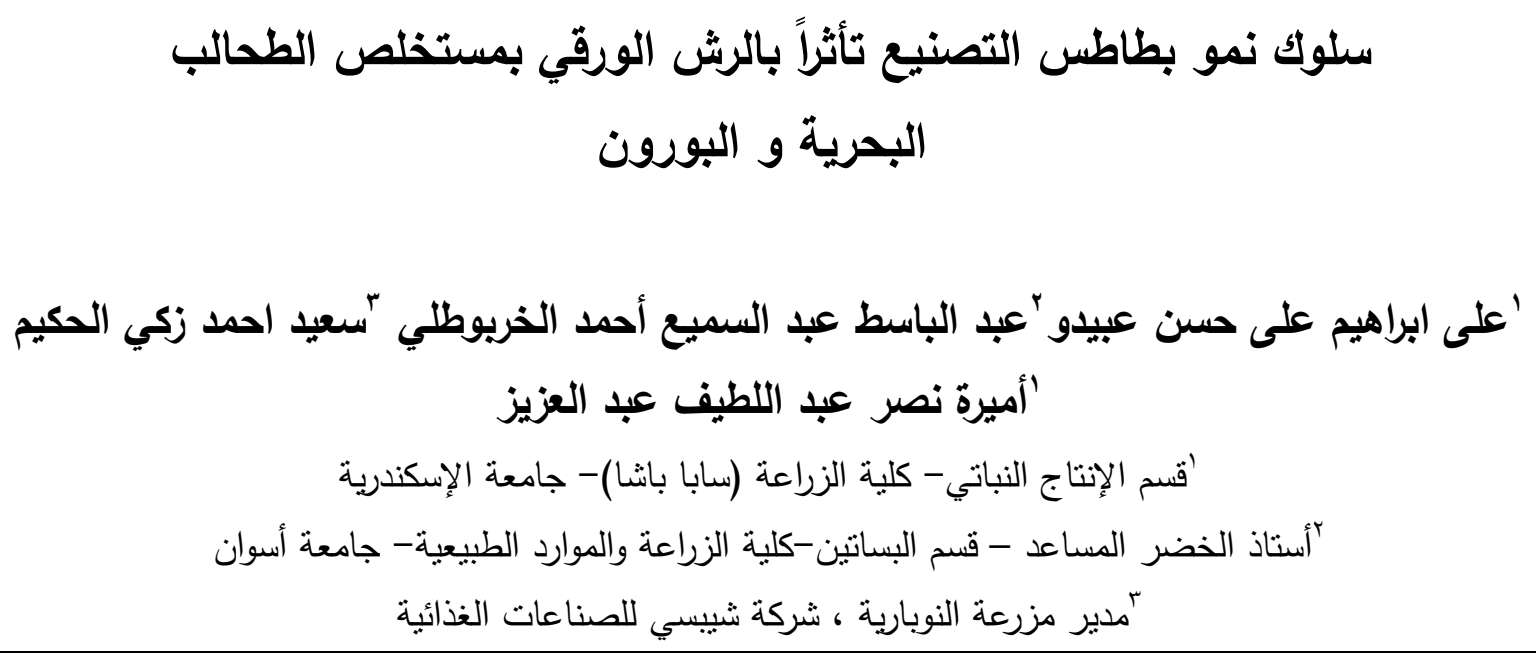

تعتبر البطاطس محصول غذائي هام للعشيرة الإنسانية ويقدم الاحتياجات الغذائية الضرورية للإنسان ويقدم العديد من العناصر الغذائية الضرورية والفيتامينات مثل بوتاسيوم، فوسفور، منجنيز، مغنسيوم ، الفيوليت، فيتامين ج ، فيتامين ب7. زيادة القدرة الإنتاجية لمحصول البطاطس عبر مستخلصات الطحالب البحرية بدلا من التسميد المعدني وبعض المغذيات الصغرى مثل البورون من أجل زيادة الإنتاجية كماً ونوعاً وصحياً لتحسين تغذية زيادة السكان. ولذلك أجريت

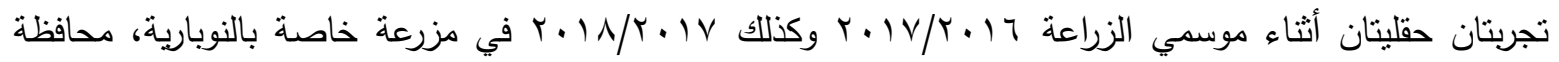
البحيرة، مصر ، تحت ظروف الحقل المكشوف في تربة طينية لدراسة تأثير الرش الهوائي

للأوراق بمستويات مختلفة من مستخلص الطحالب البحرية (كنترول، . . . . . . . . ملجم/لتر) والبورون (كنترول،

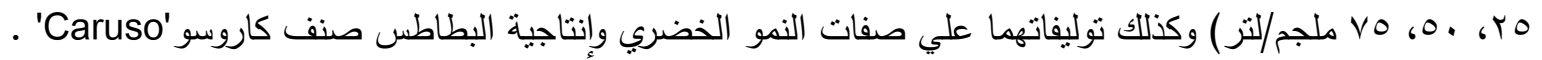
كانت كلتا التجربتين المنفذنين تجارب علمية موضوعة أوضمن التصميم الإحصائي القطاعات العشوائية الكاملة بثلاث مكررات. تضمنت كل مكررة أثني عثر معاملة، وكل معاملة كانت قد وزعت عشوائياً داخل كل قطاع فتوليفة الرش 


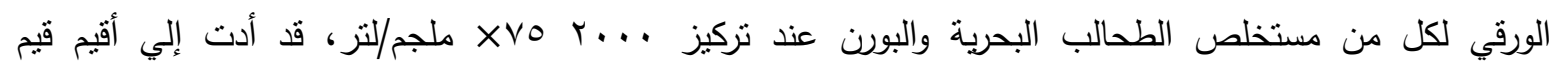

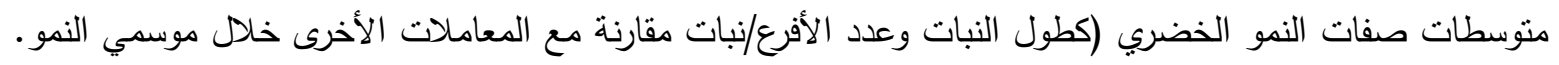

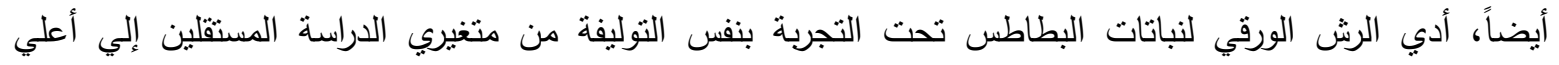

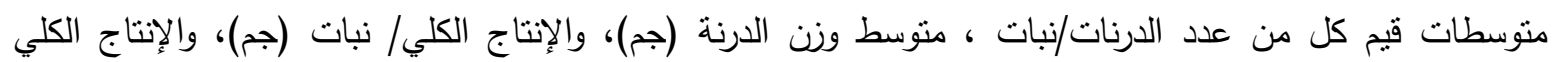

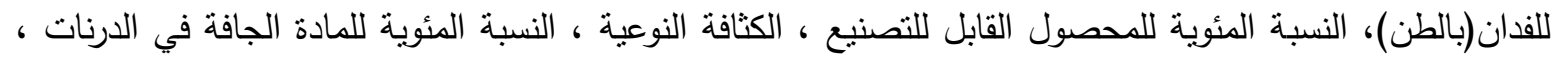

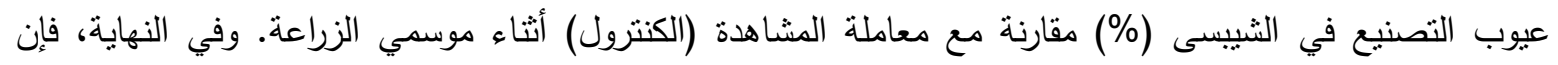

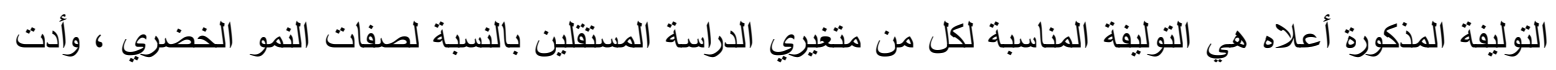

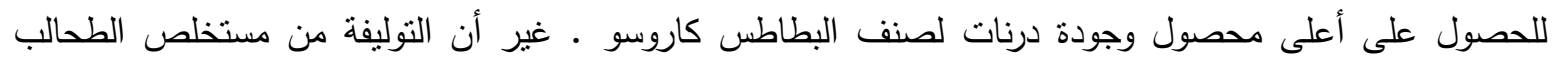

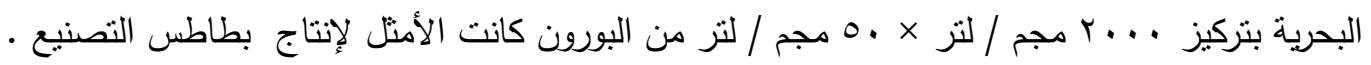

